\title{
Al-Wujuh Wa Al-Nazhair dalam Alquran Perspektif Historis
}

\author{
Wahyudi \\ Institut Agama Islam Ma'arif NU (IAIMNU) Metro Lampung \\ wahyudiragi1447@gmail.com
}

DOI: $10.29240 /$ alquds.v3i1.575

Submitted: 2018-10-16| Revised: 2019-04-16| Accepted: 2019-04-25

\begin{abstract}
This article discusses the al-wujuh wa al-naz̧hair al-Qur'an in a historical perspective. The problem of pronunciation in the Qur'an seems to have emerged since the early generations of Islam. But in its development this study has been hated because it is deemed deviated from the function of the Qur'an which is a guide book (huda) not a book of linguistic practice. This opinion cannot be taken for granted, because understanding the meaning of pronunciation is the first step to understanding the Qur'an. This study explains the history of the development of the science of al-wujub wa al-nazhair in the classical and contemporary era. Through qualitative research and the chronic historiographic approach, researchers want to examine how this scientific development is from classical and contemporary times and distorted in each period. The result is that in classical era more work appeared specifically discussing this discourse. While in the contemporary era the discourse of al-wujuh wa al-nazhair was more applicable and integrated in the commentaries. And more affected by hermeneutic thinking instead.
\end{abstract}

Keywords: al-wujuh wa al-nazhair, meaning, multimeaning

\begin{abstract}
Abstrak. Artikel ini membahas mengenai al-wujuh wa al-nazhair al-Qur'an dalam perspektif historis. Problematika makna lafal dalam al-Qur'an agaknya sudah muncul sejak generasi awal Islam. Namun dalam perkembangannya kajian ini pernah dibenci karna dianggap melenceng dari fungsi al-Qur'an yang merupakan kitab petunjuk (buda) bukan kitab praktik kebahasaan. Pendapat tersebut tidak bisa diterima begitu saja, sebab pemahaman akan makna lafal merupakan langkah awal memahami al-Qur'an. Penelitian ini menjelaskan sejarah perkembangan ilmu al-wujuh wa al-nazhair pada era klasik dan kontemporer. Melalui penelitian kualitatif dan pendekatan historiografi kronik peneliti hendak menelaah bagaimana perkembangan keilmuan ini dari masa klasik dan kontemporer serta distingsi di setiap periode. Hasilnya pada masa klasik lebih banyak muncul karya-karya yang membahas diskursus ini secara spesifik. Sementara di era kontemporer diskursus al-wujuh wa al-nazhair lebih bersifat aplikatif dan terintegratif dalam kitab-kitab tafsir. Serta lebih banyak terpengaruh pemikiran hermeneutika.
\end{abstract}

Kata kunci: al-wujuh wa al-nazhair, makna, multimeaning 


\section{Pendahuluan}

Al-Qur'an merupakan kalam Tuhan yang Shalih li kulli zaman wa makan, kalam Tuhan yang menjadi pedoman hidup bagi umat Islam yang hakiki. ${ }^{1}$ Meskipun secara faktual al-Qur'an turun di Arab, namun dalam konteksnya alQur'an berlaku untuk semua umat manusia, tidak terbatas bagi orang-orang yang berada di teritorial tanah Arab saja. Sejak kitab ini diturunkan sampai saat ini kajian terhadap ayat-ayat al-Qur'an tidak pernah habis. Kajiannya beragam, mulai dari kajian kebahasaan, sintaksis, morfologi, sampai upaya kontekstualisasi terhadap ajarannya. Pendekatan yang digunakan pun juga beragam, dewasa ini pendekatan hermeneutika menjadi "trend" di kalangan akademisi muslim. Fazlurrahman misalnya, mengembangkan teori double movement dalam upaya memahami ideal moral yang dikehendaki ayat.

Kajian kebahasaan agaknya merupakan konsentrasi awal dalam kajian alQur'an. Kasus Adi bin Abi Hatim ${ }^{2}$ yang salah dalam memahami bahasa ungkapan al-Qur'an merupakan bukti bahwa kajian kebahasaan secara embrio sudah ada sejak zaman Nabi. Pada masa sahabat, ketidaktahuan Umar mengenai maksud dari kata abban dalam al-Qur'an juga bukti lain bahwa kajian tentang bahasa al-Qur'an sudah ada sejak generasi awal Islam.

Kajian tentang kebahasaan al-Qur'an seperti sintaksis, morfologi dan lain sebagainya, hampir menjadi pembahasan wajib dalam kitab tafsir era klasik sampai era pertengahan. Hal ini menjadi sasaran kritik bagi ulama modern, terlalu "berlama-lama" dalam membahas gramatikal dalam ayat al-Qur'an kadang sampai melalaikan sisi budan / petunjuk dalam ayat yang dibahas. Hal ini seperti yang dinyatakan oleh Abduh, menurutnya kajian-kajian kebahasaan ditersebut tidak ditanyakan oleh Allah, dan umat tidak membutuhkannya, yang

1 Arif Chasbullah Chasbullah and Wahyudi Wahyudi, "Deradikalisasi Terhadap Penafsiran Ayat-Ayat Qital," FIKRI: Jurnal Kajian Agama, Sosial Dan Budaya 2, no. 2 (December 2017): 408.

${ }^{2}$ Adi bin Abi Hatim salah dalam memahami ungkapan metaforis dalam al-Qur'an. Dalam sebuah riwayat disebutkan bahwa ketika turun ayat tentang batasan waktu diperbolehkan makan dan minum ketika berpuasa (al-Baqarah ayat 187). Dalam ayat tersebut terdapat ungkapan alkhayd al-abyadh dan al-khayd al-aswad, ungkapan ini dipahami oleh Adi bin Abi Hatim dengan makna literalnya, padahal maksud dari al-khayd al-abyadh adalah terangnya siang dan al-khayd alaswad adalah gelapnya malam. 
dibutuhkan oleh umat adalah petunjuk yang mampu menghantarkan kepada kebahagiaan dunia dan akhirat. ${ }^{3}$

Namun kritik ini tidak bisa diterima begitu saja. Kajian tentang kebahasaan al-Qur'an sama pentingnya dengan kajian tentang dalalab yang dikandung di dalam ayat. Maksud dari ayat al-Qur'an tidak dapat dipahami dengan baik, jika makna kata atau susunan tarkibnya tidak diketahui dengan baik pula. ${ }^{4}$ Sebab al-Qur'an adalah kitab yang unik, bisa saja ia menyebutkan satu kata yang sama, namun memiliki arti yang berbeda ketika kata tersebut diletakkan di lain tempat. Kajian ini dalam diskursus ilmu al-Qur'an disebut dengan al-wujuh wa al-nazhair.

Penelitian ini berupaya melacak perkembangan ilmu al-wujuh wa alnazhair dari masa klasik dan kontemporer dengan menggunakan pendekatan historis sebagai pisau analisisnya. Sementara guna memudahkan proses penelitian, bentuk analisis historis dalam tulisan ini menggunakan historiografi kronik $^{5}$ yang dibatasi pada era klasik dan kontemporer saja. Melalui pendekatan ini akan diungkap bagaimana perkembangan ilmu wujuh wa nazair pada masa klasik dan kontemporer, serta menelaah distingsi di era tersebut.

Dalam penelitian ini penulis menggunakan corak library research (penelitian kepustakaan). ${ }^{6}$ Dalam hal ini data-data yang diteliti berupa bahanbahan kepustakaan, khususnya yang terkait dengan al-wujuh wa al-nazhair. Kemudian hasil penelusuran tersebut dianilisis dan diurutkan secara sistematis sesuai dengan diakronik historis.

Peneliti bukan yang pertama kali membahas tentang al-wujuh wa alnazhair. Sudah ada peneliti terdahulu yang mengkaji diskursus ini. Setidaknya kajian tentang al-wujuh wa al-nazhair yang dilakukan oleh peneliti terdahulu

${ }^{3}$ Dudung Abdullah, "Pemikiran Syekh Muhammad Abduh Dalam Tafsir Al-Manar," AdDaulab 1, no. 1 (December 2012): 38.

${ }^{4}$ Sayyid Haidar dan Fatimah Haji, "Dirasah Tahliliyah Ihshaiyah fi al-Nazha'ir alLughawiyyah fi Tafsir Majma' al-Bayan "al-Taradif wa Tabayin wa al-Ishtirak," Majalab Dirasat fi al-Lughah al-'Arabiyah wa Adabiba 18, no. 2 (2014): 95.

${ }^{5}$ Histiografi kronik adalah bentuk penelitian sejarah yang memberikan periodesasi waktu secara pasti. Lihat, Wilaela, Sejarah Islam Klasik (Riau: Fakultas Ushuluddin UIN Syarif Kasim Riau, 2016), 43.

${ }^{6}$ Mestika Zed, Metode Penelitian Kepustakaan (Yogyakarta: Buku Obor, 2008), 16. 
dapat digolongkan menjadi tiga kategori. Pertama, kajian yang membahas alwujuh wa al-nazhair dalam satu kitab tafsir tertentu. Seperti artikel Dirasah tabliliyah Ihshaiyah fi al-Naz̧hair al-Lughawiyah fi Tafsir Majma' al-Bayan al-Taradif wa al-Tabayin wa al-Ishtirak ditulis oleh al-Sayyid Haydar dan Fathimah Haji. Artikel ini diterbitkan di Jurnal Dirasat fi Lughat al-'Arabiyah wa Adabiha pada tahun 2014 yang fokus kajiannya adalah kitab Majma’ al-Bayan karya al-Thabrasy.

Ketegori kedua, adalah kajian al-wujuh wa al-nazhair secara general dalam al-Qur'an seperti yang ditulis oleh Haydar 'Ali dan diterbitkan di jurnal alUstadz pada tahun 2013 dengan judul Al-wujuh wa al-Naz̧hair fi al-Qur'an al-Karim. Penelitian ini lebih fokus ke aspek contoh-contoh lafadz dalam al-Qur'an. Ketegori ketiga, adalah kajian al-wujuh wa al-nazhair spesifik membahas satu lafadz tertentu. Misalnya Dalalat Lafz̧hah al-Nur fi al-Qur'an al-Karim wa al-Kutub al-Wujuh wa al-Nað̧air, ditulis oleh Hamidah Rahmah dan Nadi Sami. Artikel ini diterbitkan oleh jurnal Kulliyah al-Tarbiyah al-Asasiyah pada tahun 2015 dan fokus pembahasan adalah lafadz al-nur dan berbagai macam derivasinya.

Al-wujuh wa al-nazhair merupakan kajian yang penting dalam diskurusus Ulum al-Qur'an. Pengabain terhadap diskursus ini akan berimplikasi kepada hasil penafsiran yang kurang tepat. Oleh karena itu, peneliti hendak mendiskusikan kembali kajian al-wujuh wa al-nazhair dalam al-Qur'an. Namun berbeda dengan penelitian terdahulu, pendekatan yang digunakan dalam penelitian ini adalah historical approach. Dengan pendekatan ini peneliti berupaya menjelaskan perkembangan kajian al-wujuh wa al-nazhair dan bagaimana perbedaannya di setiap periodenya.

\section{Pembahasan}

Secara etimologi kata al-wujuh merupakan bentuk jama' dari kata al-wajh yang berarati sesuatu yang berada di depan. Wajh al-nahar berarti permulaan siang, wajh al-dahr berarti permulaan tahun. ${ }^{7}$ Sedang al-nazhair merupakan bentuk plural dari kata nazbir yang berarti yang sama atau sepadan. ${ }^{8}$ Dari makna dasar ini kata al-wnjub dijadikan sebagai suatu nama diskursus ilmu membahas lafallafal al-Qur'an yang memiliki beragam makna. ${ }^{9}$ Sedang al-naz̧bair adalah 1998), 41 .

${ }^{7}$ Salwa Muhammad, Al-Wujuh Wa Naz̧hair Fi Al-Qur'an Al-Karim (Kairo: Dar al-Shuruq,

8 'Ali, Atabik and Ahmad Zuhdi Muhdhar, Qamus Krapyak Al-'Ashry 'Araby Indunisy (Yogyakarta: Multi Karya Grafika, t.th), 1921.

${ }^{9}$ Muhammad, Al-Wujuh Wa Naz̧hair Fi Al-Qur'an Al-Karim, 41. 
kesepadanan makna lafal dalam al-Qur'an kendati menggunakan lafal yang berbeda, dalam kajian bahasa Inggris diskursus ini disebut dengan bomonymy. ${ }^{10}$

Sedang secara terminologi al-Suyuthi mendefinisikan al-wujuh dengan:

$$
\text { اللفظ المشترك الذي يستعمل في عدة معان }
$$

Lafadz mustarak yang yang digunakan dalam beberapa ragam makna

Sedang al-nazhair menurut al-Suyuthi adalah:

$$
\text { كالألفاظ المتواطئة }
$$

Seperti lafad yang bersesuaian. ${ }^{11}$

Namun menurut Harun bin Musa definisi al-wujuh yang ditulis oleh alSuyuthi dalam kitab al-Itqan fi 'Ulum al-Qur'an merupakan kutipan dari kitab alBurban fi 'Ulum al-Qur'an karya al-Zarkasyi, bukan definisi yang dirumuskan oleh al-Suyuthi sendiri. ${ }^{12}$ Sedang Quraish Shihab mendefinisikan al-wrijub wa alNaz̧bair dengan:

Al-wijub adalah kata yang sama sepenuhnya, dalam huruf dan bentuknya, yang ditemukan dalam berbagai redaksi (ayat), tetapi beraneka ragam makna yang dikandungnya. Al-nazahir adalah makna bagi satu kata dalam satu ayat sama dengan makna tersebut pada ayat yang lain, kendati menggunakan kata yang berbeda. ${ }^{13}$

Definisi al-wujuh wa al-nazhair yang dirumuskan oleh Quraish Shihab ini mirip dengan definisi yang dirumuskan oleh Ibn al-Jawzy :

${ }^{10}$ Ahmed Mohammed Ali Abdul Ameer, Homonymy in English and Arabic: A Contrastive Study (Babilonia: University of Babylon, 2010), 12.

11 Jalaludin al-Suyuthi, Al-Itqan Fi 'Ulum Al-Qur'an (Bairut: Muasasah al-Risalah al$\mathrm{Na}>$ shiru>n, 2008), 301.

${ }^{12}$ Harun bin Musa, Al-Wujuh Wa Naz̧hair Fi Al-Qur'an Al-Karim (t.tp: Wijarah alThaqafah wa al-A'lam Dairah al-athar wa al-Turath, 1988), 8.

${ }^{13}$ Quraish Shihab, Kaidab Tafsir (Tangerang: Lentara Hati, 2015), 119-20. 


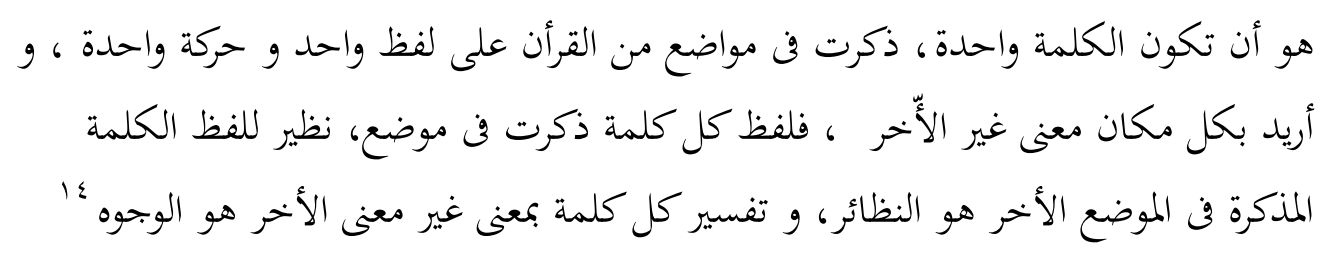

Adanya satu kata yang disebutkan dalam tempat-tempat tertentu dengan bentuk lafal dan harakat tertentu dan dimaksudkan untuk makna yang berbeda dengan tempat lainnya. Maka, kata yang disebutkan pada suatu tempat sama dengan yang disebutkan pada tempat lainnya disebut al-naz̧bair dan penafsiran makna pada setiap kata berbeda pada setiap tempatnya disebut al-wujub.

Dengan demikian, secara singkat al-wujuh dapat diartikan kesamaan lafadz namun memiliki makna yang berbeda sebagaimana contoh, kata ummah yang terulang dalam al-Qur'an sebanyak lima puluh dua kali, menurut al-Husayn al-Damaghany kata ummah dalam al-Qur'an memiliki sembilan arti, yaitu, kelompok, agama (millah), waktu yang panjang (sinin), kaum, pemimpin, generasi yang lalu, umat Muhammad, orang-orang kafir, dan ciptaan (al-khalq). ${ }^{15}$

Al-nað̧air dapat diartikan dengan lafad-lafad yang memiliki redaksi yang berbeda akan tetapi memiliki makna yang sama. Sebagaimana contoh kata bashar, insan yang keduanya bermakna manusia. qalb dan fu'ad yang diterjemahkan hati, nur dan dhiya' yang diterjemahkan cahaya dan contoh-contoh lainnya dalam alQur'an. ${ }^{16}$

Sebagian ulama ada yang berpendapat bahwa al-wujuh itu sama dengan mushtarak dan al-nazhair itu sama dengan mutaradif. Namun pendapat ini menurut Quraish Shihab tidak tepat, menurutnya ada perbedaan antara mutaradif dengan al-nazhair dan antara al-mujuh dengan mushtarak. Kalau mushtarak hanya tertuju dalam satu lafal saja, sedangkan al-wujub bisa terjadi pada lafal tunggal maupun pada rangkaian kata-kata. Sayangnya Quraish Shihab tidak memberikan contoh mengenai penjelasan ini. Adapun perbedaan mutaradif dan al-nazhair adalah pada kedalaman analisis. Ketika membicarakan kata insan sepadan (naz̧hir) dengan kata

${ }^{14}$ Muqatil bin Sulayman al-Balkhy, Al-Wujuh Wa Al-Naz̧hair Fi Al-Qur'an Al-'Azim (Baghdad: Markaz Jum'ah al-Majid li al-Thaqafah wa al-Turath, 2005), 7.

${ }^{15}$ Husayan bin Muhammad al-Damaghani, Qamus Al-Qur'an Aw Isblab\} Al-Wujub Wa AlNazhair Fi Al-Qur'an Al-Karim (Bairut: Dar al-'Ilmi li al-Malayin, 1983), 42.

${ }^{16}$ Quraish Shihab, Kaidab Tafsir, 120. 
bashar, pembahasannya hanya berhenti di sana, tidak menjelaskan apa persamaan dan perbedaannya secara lebih jauh.

Adanya al-wujuh wa al-nąhair dalam al-Qur'an dalam perspektif ulama merupakan bentuk kemu'jizatan al-Qur'an. Bukti bahwa al-Qur'an merupakan Kalam Tuhan bukan buatan manusia. Karena tidak mungkin dalam kalam manusia satu kosa kata memiliki beberapa makna. Hal ini menjadikan pembahasan al-wujuh wa al-naz̧hair materi yang mutlak harus diketahui oleh cendikiawan yang hendak memahami isi kandungan al-Qur'an. Sebuah riwayat dari Muqatil bin Sulayman yang di marfu' kan kepada nabi Muhammad menerangkan bahwa:

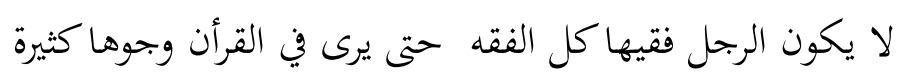

Seseorang tidak akan benar-benar paham akan al-Qur'an sampai ia mengetabui makna yang beragam di dalam al-Qur'an.

Riwayat ini menjadi argumen bahwa sesorang yang hendak memahami al-Qur'an harus mengusai materi al-wujuh wa naz̧hair. Sehingga pemahaman yang didapatkan menjadi luas tidak sempit dan kaku. Pluralitas makna yang dikandung dalam al-Qur'an sudah diisyaratkan oleh sahabat 'Ali bin Abi Thalib ketika mengutus Ibn Abbas untuk beradu argumen dengan golongan khawarij.

Dalam sebuah riwayat diceritakan bahwa sahabat 'Ali melarang Ibn Abbas menggunakan dalil al-Qur'an ketika beradu argumen dengan golongan khawarij. Instruksi ini sempat dibantah oleh Ibn Abbas karena menurutnya ia lebih paham mengenai al-Qur'an dibanding dengan golongan khawarij. Namun 'Ali menjawab bahwa al-Qur'an itu dž wujuh, sehingga apabila kamu berpendapat mereka juga akan punya pendapat lain. Menurut Sahabat Ali, hadis Nabil dalil yang tepat untuk beradu argumen dengan meraka, karena hadis tidak dž wujuh sebagaimana al-Qur'an.

Di satu sisi aspek ini mungkin menjadi bahan perdebatan yang tidak ada akhirnya. Namun di sisi lain, aspek ini menjadi bukti bahwa al-Qur'an benarbenar firman-Nya. Tidak ada ciptaan manusia yang bisa seperti ini, satu teks namun dipahami secara berbeda dan masing-masing memiliki argumen yang bisa saja sama-sama kuat. Atau bisa juga menjadikan al-Qur'an sebagai dasar dari berbagai macam kepentingan individu maupun kelompoknya. 
Secara historis kajian tentang al-wujuh wa al-nazhair berkembang seiring dengan perkembangan tafsir al-qur'an. ${ }^{17}$ Namun kemudian, para pakar bahasa dan tafsir menulis diskursus al-wujuh wa al-nazhair dalam satu buku khusus yang terpisah dari buku tafsir. Hal seperti lumrah dalam dunia akademis, satu rumpun ilmu dapat terpecah-pecah menjadi berbagai macam ilmu yang memiliki konsentrasi beragam. Dari ilmu tafsir misalnya, memunculkan ilmu qira'at, ilmu munasabah, ilmu bahasa, ilmu asbab al-nuzul dan lain sebagainya.

Dalam diskursus tafsir al-Qur'an, al-wujuh wa al-nazhair masuk dalam kategori tafsir al-Qur'an ${ }^{18}$ yang bercorak kebahasaan. Corak bahasa dalam tafsir al-Qur'an begitu kental di periode klasik dan pertengahan Islam. Hampir setiap karya tafsir tidak lepas dari pembahasan perihal 'asal kata, gharib al-Qur'an, Mushkil al-Qur'an, mushabihah al-Qur'an dan I'rab al-Qur'an. Memang sejak awal perkembangannya, ilmu al-Qur'an selalu saling terkait dengan ilmu bahasa, seolah dua rumpun ini tidak dapat dipisahkan. Banyak kajian yang telah dilakukan oleh para ulama yang terkait dengan bahasa al-qur'an yang dituangkan dalam banyak karya tulis.

Hasil dari ulama yang konsen dalam bidang ini adalah temuan bahwa ada satu lafal dalam al-Qur'an yang memiliki satu makna saja, adapula yang satu lafal memiliki dua makna bahkan ada yang memiliki banyak makna (multi-meaning). Mereka menjelaskan makna yang kuat dan makna yang samar dalam lafal tersebut. Namun terkadang terjadi perdebatan di kalangan ulama perihal mana makna yang kuat dan makna yang samar. ${ }^{19}$ Perdebatan mengenai makna hakiki dan majazi ini hal yang mainstream dalam periode Islam pertengahan, dimana sekte muktzilah vis a vis dengan sekte suni.

Dalam beberapa literatur yang membahas khusus mengenai al-wujuh wa al-naz̧hair disebutkan bahwa kitab yang paling tua membahas mengenai al-wujuh wa naz̧hair adalah kitab karya Muqatil bin Sulayman al-Balkhy (w. $150 \mathrm{H}$ ) ${ }^{20}$ Kitab tersebut diberi nama al-mujuh wa naz̧hair fi al-Qur'an al-Karim, ditulis pada abad ke

${ }^{17}$ Sayyid Muhammad Ridha, "Dirasah Naqdiyah Fi Kutub Al-Wujuh Wa Nazahir," AlAfaq Al-Hadharah Al-Islamiyab 15, no. 1 (1391): 1.

${ }_{18}$ Muhammad Yusuf, "Ilmu Wujuh Wa Nazhair Fi Al-Qur'an Al-Karim Wa Atharuh Fi Tafsir Wa Kashaf 'an I'jaz Al-Qur'an,” Majalah Jami'ah Dimasqi 19, no. 2 (2003): 456.

${ }^{19}$ Jalaludin al-Suyuthi, Al-Iklil Fi Istimbath Al-Tanæill (Bairut: Dar Kutub al-Ilmiyah, 1985), 13.

${ }^{20} \mathrm{Jamal}$ al-Din Abi Faraj Abd al-Rahan al-Jawzi, Nuðhah Al-A'yun Al-Nawazhir Fi Tlm AlWujuh Wa Al-Naz̧hair (Bairut: Muasasah al-Risalah al-Nashirun, 1987), 49. 
dua Hijriah. Namun bukan berarti sebelum masa Muqatil bin Sulayman alBalkhy belum ada pembahasan mengenai al-wujuh. Sangat mungkin sebelum masa Muqatil bin Sulayman al-Balkhy ini sudah ada ulama yang konsen membahas mengenai al-wujuh wa nazhair akan tetapi kitab-kitabnya tidak terkodifikasikan secara baik. Sehinggga tidak sampai pada generasi Islam saat ini.

Asumsi ini berdasarkan keterangan Hatim Shalih pen-tahqiq kitab alwujuh wa nazhair fi al-Qur'an al-Karim, bahwa kitab karya Muqatil bin Sulayman ini adalah kitab tertua yang sampai pada zaman kita, ${ }^{21}$ dengan demikian sangat dimungkinkan terdapat kitab-kitab terdahulu yang tidak sampai pada zaman kita. Di antaranya kitab yang berbicara tentang al-wujuh wa naz̧hair, namun tidak sampai ke generasi Islam saat ini adalah kitab Kashfa al-dbunun yang dinisbatkan kepada 'Ikrimah maula Ibn 'Abbas. ${ }^{22}$

Selain itu, istilah al-mujuh secara sharih sudah dikenal pada masa khalifah Ali bin Abi Thalib. Sebagaiaman riwayat berikut :

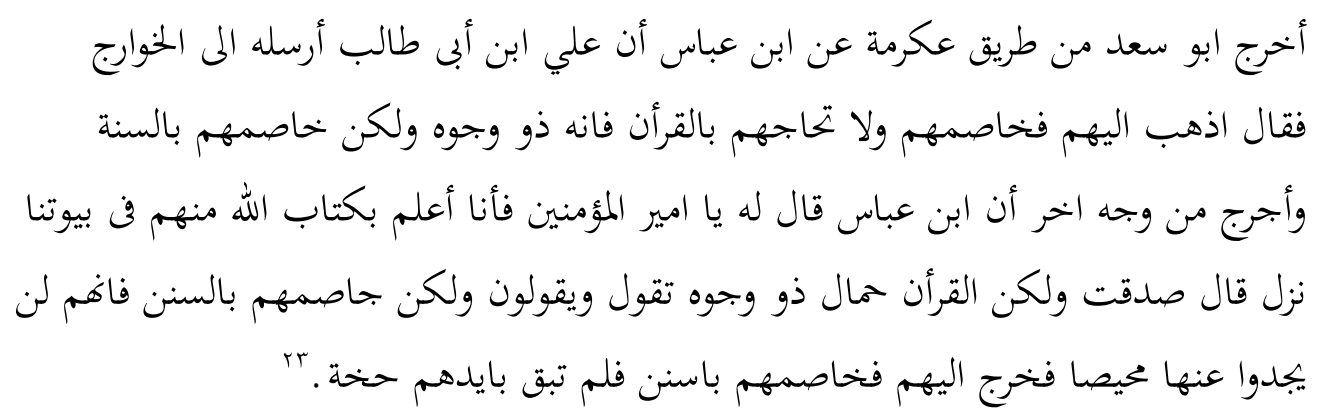

Abu Sa’id mempublikasikan (riwayat) dari jalur Ikrimah dari Ibn Abas babwa Ali mengutus Ibn Abbas untuk bertemu dengan golongan khawarij. Maka Ali berkata (kepada Ibn Abas), pergilah kepada mereka maka debatlah mereka dan janganlah engkan menggunakan dalil al-Qur'an karena sesunggubnya al-Qur'an itu dzu wujuh akan tetapi debatlah dengan al-sunnah. Riwayat dari jalur lain menyebutkan sesunggubnya Ibn Abbas berkata kepada Ali, wahai Amir al-mu'minin aku lebih tahu tentang al-Qur'an dibandingkan dengan mereka di rumah kami al-Qur'an diturunkan. Ali menjawab, kamu benar, akan tetapi al-Qur'an mengandung banyak kemungkinan makna (dzu wujub), engkau berpendapat, mereka juga memiliki pendapat (yang berbeda), tetapi debatlah mereka

\footnotetext{
${ }^{21}$ al-Balkhy, Al-Wujub Wa Al-Naz̧air Fi Al-Qur'an Al-'Az̧ $>m, 7$.

22 Muhammad, Al-Wujuh Wa Ną̧air Fi Al-Qur'an Al-Karim, 19.

23 al-Suyuthi, Al-Itqan Fi 'Ulum Al-Qur'an, 302.
} 
dengan al-sunah, karena mereka tidak akan menemukan dalam al-sunnah tempat berlari (bujjab). Maka Ibn Abbas keluar dan mendebat mereka dengan dalil sunah, maka mereka tidak memilki buijah (dari hadis).

Dengan demikian asumsi bahwa sebelum Muqatil bin Sulayman sudah ada ulama yang membahas mengenai pembahasan ini semakin kuat. Setelah masa Muqatil bin Sulayman masih banyak ulama yang konsen membahas mengenai al-wujuh wa nazbair.

Menurut Salwa Muhammad ada sekitar tiga belas karya yang berbicara mengenai diskursus wujuh wa al-Nazair dalam al-Qur'an. Tujuh di antaranya sudah dicetak dan diterbitkan dalam bentuk buku, sementara sisanya masih berupa manuskrip. Dalam kitab Nuşah al-A'yun al-Nawadhir fi $\mathrm{Ilm}$ al-Wujub wa Nazabir, Jamaluddin Abu Faraj merinci kitab-kitab yang membahas mengenai alwujuh wa al-nazhair dan sampai kepada generasi saat ini, baik itu yang terbukukan secara baik maupun yang berupa manuskrip. Ia menyebutkan secara kronologis sebagai berikut :

1. Al-asbah wa al-Nazhair fi al-Qur'an al-Karim karya yang dinisbahkan kepada Muqatil bin Sulayman (w.150 H). Dalam kitab ini, Muqatil bin Sulaiman mengumpulkan lafal-lafal dalam al-Qur'an dan menafsirkannya dengan berbagai macam makna yang dikandungnya. Sistematikanya, Muqatil menuliskan lafal yang hendak ditafsirkan kemudian diikui oleh maknamakna yang dikandung oleh lafal tersebut tanpa terpisah, kecuali kalau memang ada hal-hal yang menghendaki untuk dipisahkan.

2. Kitab yang diriwayatkan Mathruh bin Muhammad bin Shakir (w. $271 \mathrm{H}$ ), dari Abdullah bin Harun al-Hijazi (hidup pada masa al-Thawri dan wafat pada tahun $161 \mathrm{H}$ ) dari ayahnya yang berjudul al-Wujuh wa al-Nazhair. Kitab ini berupa manuskrip, di antara naskah manuskripnya berada di Hyderabad India. Sementara naskah manuskrip lainnya berada di salah satu perpustakaan di Irlandia.

3. Al-Tashrif karya Yahya bin Salam (w. $200 \mathrm{H}$ ) ditulis pada abad ke II H. Kitab ini terdiri dari beberapa paragraf. Setiap paragraf dalam kitab ini berisi kalimat-kalimat al-Qur'an, kemudian penulis menyebutkan makna-makna yang dikandung dalam ayat tersebut. Kitab ini tidak ditulis berdasarkan sistematika huruf hijaiyah. ${ }^{24}$

4. Tabshil Nazhair al-Qur'an karya Hakim al-Tirmidzi (w. 320 H). Kitab ini ditulis pada kisaran abad ke III H. Di dalam kitab ini ditulis sebanyak delapan puluh satu lafad multi-meaning. Dalam kitab ini al-Tirmidzi

${ }^{24}$ Muhammad, Al-Wujuh Wa Ną̧hair Fi Al-Qur'an Al-Karim, 25. 
menjelaskan bahwa meskipun satu lafal memiliki arti yang beragam pada dasarnya ia kembali pada satu makna.

5. Al-Ashbah wa al-Nazhair karya ini dinisbahkan kepada al-Tha'alaby (w. 429 H). Manuskrip kitab ini berada di Institusi manuskrip Arab.

6. Wujuh al-Qur'an karya Abi Abd al-Rahman Ismail bin Ahmad al-Dharir alNaisaburi (w. $430 \mathrm{H}$ ). Manuskrip kitab ini dapat ditemui di Universitas Cambridge Inggris.

7. Ishlab al-Wujuh wa al-Nazhair fi al-Qur'an al-Karim kitab ini dinisbahkan kepada Husayn bin Muhammad al-Damaghany, akan tetapi ada yang berpendapat mungkin nisbah yang benar adalah kepada Abi Abdillah Muhammad bin Ali bin Muhammad al-Damaghany (w. $487 \mathrm{H}$ )

8. Nazhah al-A'yun al-Naz\}a $>$ ir fi $\mathrm{Ilm}$ al-Wujub wa al-Nazhair karya ibn al-Jawzy (w. $597 \mathrm{H}$ ). Dalam kitab ini Ibn Jawzi menjelaskan tentang metodologi penyusunan kitab-kitab wujuh wa al-nazair terdahulu. Kemudian ia memberikan keterangan perihal definisi dan ruang lingkup ilmu ini.

9. Wujuh al-Qur'an karya Abi al-'Abbas Ahmad bin 'Ali al-Muqri' (w. $658 \mathrm{H}$ ). Manuskrip kitab ini berada di museum Inggris.

10. Al-Muntakhaf min Kitab Tuhfah al-Walad karya Ahmad bin Muhamad alHadadi. Manuskrip kitab ini berada di Dar Kutub al-Mishriyyah.

11. Kashf al-Sarair 'An Ma'na al-Wujuh wa al-Narhair ditulis oleh Syamsudin Muhammad bin Muhammad bin 'Ali bin al-'Amad (w. 887 H). Kitab ini dicetak pada tahun $1977 \mathrm{M}$ di Iskandariyah.

12. Kitab karya Musthafa bin Abdirahman bin Muhammad al-Arizi (w. $1155 \mathrm{H}$ ). Kitab ini berbentuk manuskrip dan dapat ditemukan di Dar al-Kutub alMishriyyah.

13. Kitab Bayan Wajh Ma'ani al-Alfazh al-Qur'aniyyah, penulis kitab ini tidak diketahui dan hanya berbentuk manuskrip. ${ }^{25}$

14. Kashf al-sara'ir fi Ma'na al-Wujub wa al-Asbbah wa al-Nazhair karya Ibn al'Ummad al- Mis\}ry (w. $887 \mathrm{H}){ }^{26}$

Selain kitab yang disebutkan di atas, terdapat kitab yang tidak dapat diwarisi generasi saat ini, hanya bisa diketahui melalui makbthuthath Di antaranya adalah:

1. Kitab karya 'Ikrimah bin Abdullah al-Madani mawla Ibn 'Abbas (w. $105 \mathrm{H}$ ). Kitab ini tidak sampai ke generasi saat ini, namun pernah di disebutkan oleh

\footnotetext{
25 al-Jawzi, Nuz̧hah Al-A'yun Al-Nawadzir Fi Tlm Al-Wujuh Wa Al-Naz̧hair, 53.

${ }^{26}$ Harun bin Musa, Al-Wujuh Wa Nazhair Fi Al-Qur'an Al-Karim, 9.
} 
32 | AL QUDS : Jurnal Studi Alquran dan Hadis vol. 3, no 1, 2019

Ibn Nadim dalam al-fahrisat dan disebutkan juga ileh Ibn Jawzi dalam muqaddimah kitabnya.

2. Kitab karya Ali bin Abi T \}alhah al-Hashimi (w. $143 \mathrm{H}$ ), kitab ini pernah disebutkan oleh Fuad Abd al-Baqi. Abd al-Baqi mentakhrij beberapa lafad di Shahih Bukhari dan dinisbatkan kepada Ibn Abbas dari Ali bin Abi Thalhah. Kitab ini diberi nama Gharaib al-Qur'an.

3. Kitab karya Muhammad bin Sa'ib al-Kalaby (w. $146 \mathrm{H}$ ), kitab ini pernah disebut oleh Ibn Nadim dan Ibn al-Jawzi.

4. Kitab karya Abi al-Fadl al-'Abbas bin Fadhl al-Anshari (w. 186 H), kitab ini pernah disebutkan oleh Ibn al-Jawzi dalam muqadimah kitabnya.

5. Kitab karya Ahmad bin Faris al-Lughawi (w. $390 \mathrm{H}$ ), kitab ini pernah disebutkan oleh al-Zarkasyi dalam kitab al-Burhan fi 'Ulum al-Qur'an karyanya. Dan masih banyak lagi kitab-kitab yang tidak sampai ke generasi saat ini. ${ }^{27}$

Berdasarkan data di atas terlihat bahwa kitab al-wujuh wa al-nazhair sudah muncul sejak abad ke II H. Bahkan pada abad ini, yang merupakan masa kekuasaan bani Abbasiyah lebih banyak muncul kitab al-wujuh wa al-nazhair di bandingkan dengan abad-abad setelahnya. Selain faktor waktu berkuasa yang cukup lama, perhatian bani Abbasiyah terhadap ilmu pengetahuan agaknya turut memberikan konstribusi di abad ini. Bahkan jika diakumulasikan, kitab-kitab alal-wujuh wa al-nazhair banyak muncul pada masa kekuasaan bani Abbasiyah. ${ }^{28}$ Sementara kitab-kitab yang tercatat muncul setelahnya berdasarkan data di atas hanya ada tiga kitab.

Dalam ranah aplikasi, ulama telah banyak melakukan penelitian, baik mengenai al-wujuh wa al-nazhair maupun mengenai mushtarak dan mutaradif. AlZarkasyi dalam al-Burhan fi 'Ulum al-Qur'an mengutip pendapat ulama yang menggunakan rumus atau kaidah menyangkut sekian kosa kata dengan menyatakan bahwa "semua kata ini dalam al-Qur'an bermakna ini, kecuali ayat ini”. salah satu rujukan al-Zarkasyi dalam hal ini adalah Ibn Faris penulis kitab al-Afrad. ${ }^{29}$ Cara ini juga diikuti oleh al-Suyuti dalam al-Itqan fi 'Ulum al-Qur'an.

27 al-Jawzi, Nuz̧hah Al-A'yun Al-Nawaz̧bir Fi Tlm Al-Wujub Wa Al-Naz̧bair, 50-55.

${ }^{28}$ Bani Abbasiyah berkuasa dalam rentan waktu yang lama mulai dari tahun $132 \mathrm{H}$ sampai dengan $656 \mathrm{H}$.

${ }^{29}$ Badr al-Din Muhammad Bin Abdullah al -Zarkasyi, Al-Burban Fi Ulum Al-Qur'an (Kairo: Dar al-Turath, t.th), 105. 
Misal ketika al-Zarkasyi menjelaskan makna kata al-buruj. Menurut keterangan yang beliau ambil dari Ibn Faris bahwa semua lafaz al-buruj dalam alQur'an bermakna al-kawakib kecuali pada surat an-Nisa' surat 78 :

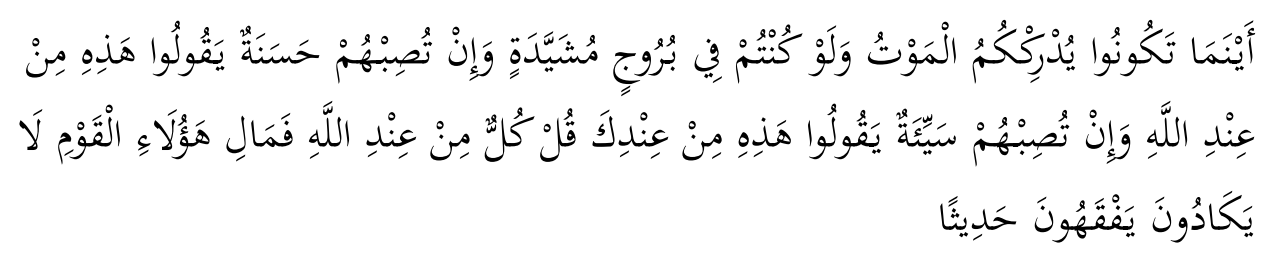

Khusus pada ayat ini kata buruj bermakna al-Qushur al-thuwal al-murtafa'ah fi al-sama', al-bashinah. Contoh lain, ketika semua kata ashbab al-nar dalam alQur'an memiliki arti abl al-nar kecuali dalam surat al-Mudatsir ayat 31 :

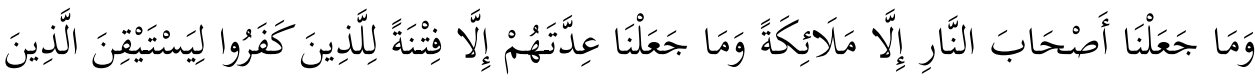

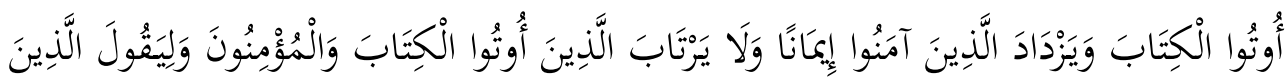

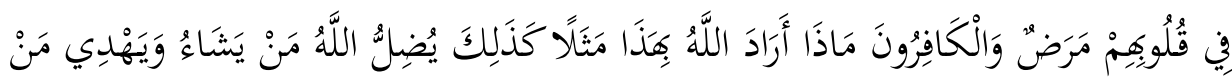

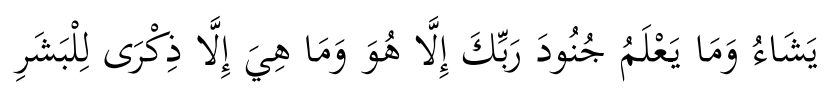

Pada ayat di atas kata ashab al-nar bukan bermakna abl al-nar akan tetapi berarti penjaga neraka. Hal seperti ini banyak disebutkan dalam kitab al-Burban karya al-Zakasyi maupun al-Itqan karya al-Suyuthi. Di dalam kitab al-wujuh wa alnaz̧hair yang ditulis oleh Muqatil ibn Sulayman banyak dituliskan tentang lafallafal yang beredaksi sama namun memiliki makna yang berbeda antara satu tempat dengan tempat lainya dalam al-Qur'an. Di antaranya lafal furqan menurut Muqatil ibn Sulayman memiliki tiga makna yakni:

1. Bermakna al-Qur'an, sebagaimana yang surat al-Furqan ayat 1:

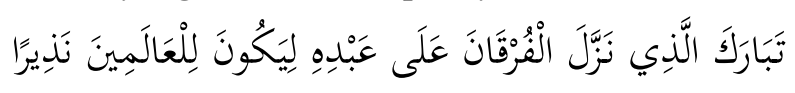

2. Bermakna al-Nas\}r (pertolongan), contohnya dalam surat al-Baqarah ayat 53:

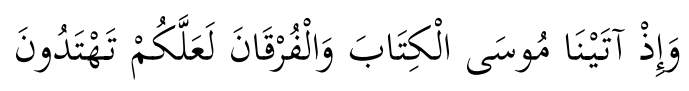

Al-furqan pada ayat di atas berarti pertolongan, membedakan antara yang haq dan yang batil serta pertolongan dari musuh-musuh.

3. Bermakna al-makhraj min al-Dhalal, sebagaimana dalam surat al-Baqarah ayat 185: 


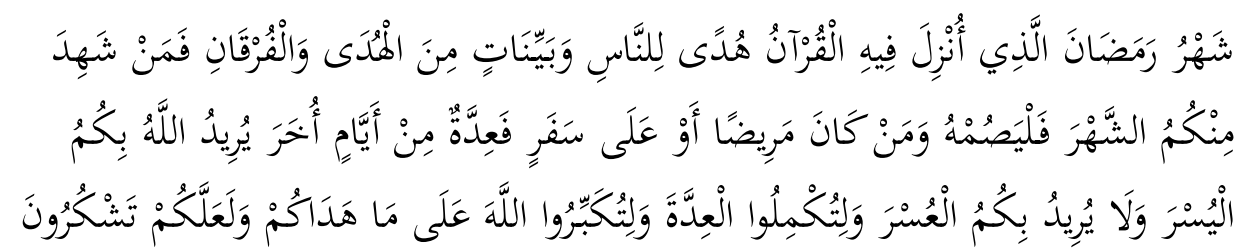

Al-furqan pada ayat di atas memiliki makna jalan keluar dari kesamaran dan kesesatan..$^{30}$

Pada masa kontemporer ini ulama yang memberikan perhatian besar mengenai penggunaan kosa kata dalam al-Qur'an diantaranya adalah 'Aishah Abdurrahman bint Shathi' dalam buku al-tafsir al-bayan. Di sana dikemukakan, bahwa hal pertama yang hendaknya dilakukan oleh cendikiawan yang meneliti tentang kosa kata al-Qur'an adalah menghimpun semua kata yang digunakan alQur'an yang menyangkut objek bahasannya sambil memperhatikan arti-arti yang dikandungnya. Kemudian memperhatikan penggunaan al-Qur'an terhadap kata itu dengan jalan memperhatikan redaksi ayat secara menyeluruh, bukan pada kata yang di bahas secara berdiri sendiri terlepas dari konteksnya. Sebagai contoh, hasil penelitian bint Shati' tentang kata ni'mah dan na'im dalam alQur'an. bint Shati' menarik kesimpulan bahwa kata na'im digunakan untuk nikmat-nikmat ukhrawi bukan duniawi. ${ }^{31}$ Dengan demikian tidak tepat jika kata na'im dalam firmanya :

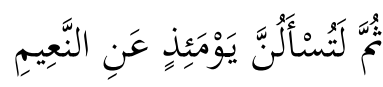

Dalam arti kenikmatan duniawi, tetapi ayat tersebut agaknya bermaksud menjelaskan bahwa kelak di Hari Kemudian semua manusia akan diminta pertanggungjawaban menyangkut sikapnya terhadap Hari Kemudian, dalam konteks ayat ini berarti surga dan aneka kenikmatannya. Apakah dia percaya wujud dan keniscayaannya atau tidak. ${ }^{32}$

Berdasarkan pengamatan Quraish Shihab, hal serupa juga dilakukan oleh al-Thabathaba'i dalam tafsir al-Mizan. Di dalam tafsir tersebut membahas mengenai makna kata sirath dan perbedaannya dengan kata sabil. Ia menarik kesimpulan bahwa sirath adalah jalan yang lebar yang hanya mengantar kepada Karim, 360.

30 al-Damaghani, Qamus Al-Qur'an Aw Isblah Al-Wujub Wa Al-Naz̧bair Fi Al-Qur'an Al-

31'Aishah Abd al-Rahman Bint Shathi', al-Tafsir al-Bayani li al-Qur'an al-Karim, Vol. I (t.tp: Dar al-Ma'arif. T.th), 216.

${ }^{32}$ Quraish Shihab, Kaidab Tafsir,125. 
kebaikan, keadilan dan hak. Sirat $\}$ hanya satu, karena itu tidak ditemukan bentuk jama'nya. Ini berbeda dengan kata sabil, yang merupakan jalan kecil dan banyak. Hal ini dibuktikan dengan ditemukannya bentuk jama' kata sabil dalam al-Qur'an.

Akan tetapi perkembangan pada masa kontemporer tidak terkodifikasi secara utuh dalam satu buku. Pada era ini lebih menekankan aspek aplikatif dan cenderung bernuansa hermeneutis. Kecenderungan hermeneutis terlihat dalam model pemahaman bint Shathi, ia menyatakan bahwa pemahaman akan kosa kata tidak bisa dilepaskan dari aspek konteksnya. Model pemahaman seperti ini merupakan salah satu ciri dari hermeneutik.

Kecenderungan pemikir al-Qur'an terhadap hermeneutika agaknya bukan suatu hal yang baru. Banyak pemikir Islam kontemporer yang berupaya memahami teks-teks keagamaan dengan pendekatan ini. Meskipun sampai sekarang penggunaan hermeneutika dalam memahami teks-teks keagamaan masih menjadi kontroversi.

\section{Kesimpulan}

Secara historis embrio ilmu al-wujuh wa al-nazhair sudah ada sejak generasi Islam awal. Tetapi pembahasan secara utuh dalam satu kitab baru muncul pada abad ke II H di masa kekhalifahan bani Abbasiyah. Di abad ini terdapat banyak kitab yang membahas diskursus al-wujuh wa al-nazhair. sedangkan pada abad-abad setelahnya, kitab tentang al-wujuh wa al-nazhair masih muncul tapi tidak sebanyak pada abad ke II H.

Sementara di era kontemporer perkembangan al-wujuh wa al-nazhair tidak dalam bentuk satu karya buku yang spesifik. Di era ini, kajian al-wujuh wa al-nazhair terintregasi dalam satu kitab tafsir atau dalam buku-buku pemikiran. Al-wujuh wa al-nazhair di periode ini lebih mengedepankan aspek praktikalaplikatif dan cenderung bernuansa hermeneutis.

\section{Bibliografi}

Abdullah, Dudung. "Pemikiran Syekh Muhammad Abduh Dalam Tafsir AlManar." Ad-Daulab 1, no. 1 (December 2012): 10.

'Ali, Atabik, and Ahmad Zuhdi Muhdhar. Qamus Krapyak Al-'Ashry 'Araby Indunisy. Yogyakarta: Multi Karya Grafika, t.th.

Ameer, Ahmed Mohammed Ali Abdul. Homonymy in English and Arabic: A Contrastive Study. Babilonia: University of Babylon, 2010. 
Balkhy, Muqatil bin Sulayman al-. Al-Wujuh Wa Al-Nazhair Fi Al-Qur'an Al'Azhim. Baghdad: Markaz Jum'ah al-Majid li al-Thaqafah wa al-Turath, 2005.

Chasbullah, Arif Chasbullah, and Wahyudi Wahyudi. "Deradikalisasi Terhadap Penafsiran Ayat-Ayat Qital.” FIKRI: Jurnal Kajian Agama, Sosial Dan Budaya 2, no. 2 (December 2017): 407-424.

Damaghani, Husayan bin Muhammad al-. Qamus Al-Qur'an Aw Ishlah Al-Wujuh Wa Al-Naz̧hair Fi Al-Qur'an Al-Karim. Bairut: Dar al-'Ilmi li al-Malayin, 1983.

Harun bin Musa. Al-Wujuh Wa Naz̧bair Fi Al-Qur'an Al-Karim. t.tp: Wijarah alThaqafah wa al-A'lam Dairah al-athar wa al-Turath, 1988.

Jawzi, Jamal al-Din Abi Faraj Abd al-Rahan al-.Nuz̧bah Al-A'yun Al-Nawaz̧bir Fi Ilm Al-Wujub Wa Al-Naə̧hair. Bairut: Muasasah al-Risalah al-Nashirun, 1987.

Muhammad, Salwa. Al-Wujuh Wa Naz̧air Fi Al-Qur'an Al-Karim. Kairo: Dar alShuruq, 1998.

Ridha, Sayyid Muhammad. "Dirasah Naqdiyah Fi Kutub Al-Wujuh Wa Nazahir." Al-Afaq Al-Hadharah Al-Islamiyah 15, no. 1 (1391).

Sayyid Haidar, and Fatimah Haji. "Dirasah Tahliliyah Ihshaiyah Fi Al-Nazha'ir Al-Lughawiyyah Fi Tafsir Majma' Al-Bayan "al-Taradif Wa Tabayin Wa Al-Ishtirak." Majalah Dirasat Fi Al-Lughah Al-'Arabiyah Wa Adabiba 18, no. 2 (2014).

Shihab, Quraish. Kaidab Tafsir. Tangerang: Lentara Hati, 2015.

Suyuthi, Jalaludin al-. Al-Iklil Fi Istimbath Al-Tanæil. Bairut: Dar Kutub alIlmiyah, 1985.

- Al-Itqan Fi 'Ulum Al-Qur'an. Bairut: Muasasah al-Risalah al-Nashirun, 2008.

Wilaela. Sejarah Islam Klasik. Riau: Fakultas Ushuluddin UIN Syarif Kasim Riau, 2016.

Yusuf, Muhammad. "Ilmu Wujuh Wa Nazhair Fi Al-Qur'an Al-Karim Wa Atharuh Fi Tafsir Wa Kashaf 'an I'jaz Al-Qur'an." Majalab Jami'ah Dimasqi 19, no. 2 (2003).

Zarkasyi, Badr al-Din Muhammad Bin Abdullah al. Al-Burban Fi Ulum AlQur'an. Kairo: Dar al-Turath, t.th.

Zed, Mestika. Metode Penelitian Kepustakaan. Yogyakarta: Buku Obor, 2008. 